\title{
Application of fluorescence technique in studying dental caries
}

- Pham Thi Hai Mien

- Tran Van Tien

- Huynh Quang Linh

Ho Chi Minh city University of Technology, VNU-HCM

(Manuscript Received on August 01 ${ }^{\text {st }}$, 2015, Manuscript Revised August 27 ${ }^{\text {th }}$, 2015)

\section{ABSTRACT:}

The aim of the present study was to investigate the fluorescence properties of sound teeth and teeth with different types of lesions. Using light-emitting diodes operating in the near ultraviolet (UVA) spectral regions for excitation, the obtained fluorescence images and spectra of carious teeth were different from sound teeth spectra due to the presence of bacteria Streptococcus mutans producing metabolites called porphyrins. The sound teeth showed the blue fluorescence with broad emission spectra from $410 \mathrm{~nm}$ to $650 \mathrm{~nm}$ (maxima at $450 \mathrm{~nm}, 500 \mathrm{~nm}$ and $520 \mathrm{~nm}$ ), while the carious regions illuminated the red light with three new peaks at $625 \mathrm{~nm}$, $650 \mathrm{~nm}$ and $690 \mathrm{~nm}$. The intensity of the red fluorescent signal depends on the density of the bacteria. Based on the red fluorescence emitted by porphyrins, not only the surface lesions but also the caries hiding under the enamel layer can be detected by UVA exciting. These results provide the ability to apply fluorescence technique in the development of an early dental diagnostic tool with a number of advantages such as safety, mobility, low cost and rapid test time.

Key words: fluorescence, dental caries, early diagnosis.

\section{INTRODUCTION}

Dental caries is one of the most popular diseases of humans worldwide. In Vietnam, according to statistics of Vietnam Odonto Stomatology Association, dental caries affects $75 \%$ of the population. The detection of carious lesions has been primarily a visual process, based principally on clinical-tactile inspection and radiographic examination [1].

Visual-tactile examination has been widely used in dental clinics for detecting carious lesions on all surfaces. A major shortcoming of this method is very limited for detecting noncavitated lesions in dentin or posterior proximal and occlusal surfaces [2]. Many studies have shown that visual-tactile examination should be associated with other caries detection methods, such as X-ray based methods, because some carious lesions may go undetected during visual examination [3, 4]. However, all X-ray based methods can cause damage to cells in the body, which in turn can increase the risk of developing cancer.

Researchers are developing tools that are sensitive and specific enough for the current presentation of caries. One of the newly developed diagnostic procedures employs fluorescence diagnostics with low-intensity lasers and non-laser light sources. Two fluorescence techniques are well-established: quantitative light-induced fluorescence, which is 
used primarily in caries research, and laserinduced fluorescence, a commercially available method used in clinical dental practice $[5,6]$.

This investigation is a part of clinical trial for introduction of dental caries diagnostic technique based on fluorescence imaging. Many investigators have observed that the healthy teeth emits blue or green fluorescence when irradiated with UVA [7, 8]. Having the lowest photon energy of the three ultraviolet wavebands, UVA has little effect on microbial pathogens and virtually no effect on human tissue with shortterm exposures [9]. Some researchers [10, 11] reported distinct high fluorescence emissions in the red region relating to metallo-, copro-, and protoporphyrins of bacteria in the carious cavity. Based on difference in fluorescence colors the carious lesions can be detected even at the early stage. In this paper, using light-emitting diodes operating in the near ultraviolet spectral regions, fluorescence imaging and spectroscopy techniques were incorporated into studying fluorescence properties of healthy and carious human dentine samples.

\section{MATERIALS AND METHODS}

\subsection{Samples}

The experiments were made on extracted teeth (in vitro) randomly collected from dental office of University Medical Center HCMC. All samples, without dental restorations to ensure the presence of questionable occlusal caries, were classified according to the visual criteria of the International Caries Detection \& Assessment System (ICDAS) [12]. Before measuring the teeth were washed in running tap water and dried for removal of stains.

\subsection{The optical systems}

For studying the fluorescence properties of teeth the majority of investigators have used lasers for exciting samples due to its advantage of high efficiency [6-8]. However, the purpose of this research is the application of fluorescence in designing a portable, compact and inexpensive dental diagnostic tool, for that the lasers are not suitable. In the previous study [13] we had tested the power LEDs emitting 380-nm peak in exciting teeth samples. The results showed that the high fluorescence intensity of all obtained images is available for the unaided eye observation. Therefore, the 380-nm LEDs was chosen in this study.

The fluorescence imaging was obtained by using the optical system shown schematically in Figure 1(a): sample (1), 10x-magnification system (2), DSLR camera (3), UV filter (4), LED (5), power source (6). The light source was a 380 nm LED driven by a stabilized power source Agilent/HP 6632B 20 Volt 5 Amp Power Supply. One UV bandpass filter (UG-1, Edmund Optics) passes only UV light and eliminates unwanted visible light from the LED. A 10x-magnification multiple lens system was used for magnifying fluorescence images taken by a Canon DSLR camera 550D.

Model of fluorescence spectroscopy instrumentation is presented in Figure 1(b): sample (1), lens (2,3), monochromator (4), computer (5), UV filter (6), LED (7), power source (8). The MS257 $1 / 4 \mathrm{~m}$ monochromator (Newport corp.) is connected to the computer via specialized software. The lens system focuses fluorescent light from the measured matters to the monochromator. 


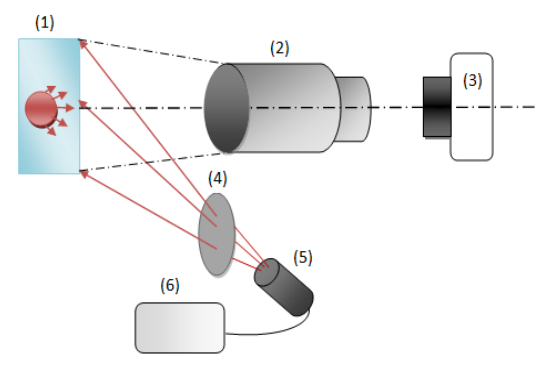

(a)

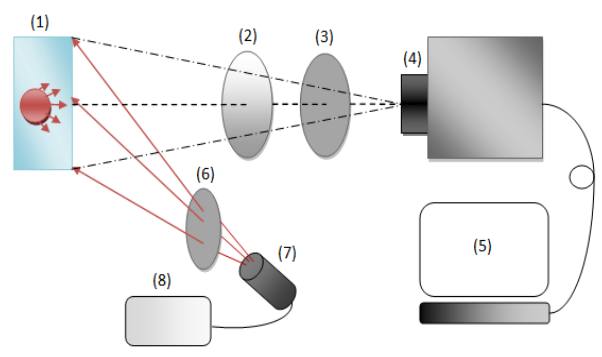

(b)

Figure 1. Schematic diagrams of the experimental setup used for fluorescence photography (a) and fluorescence spectroscopy (b).

\section{RESULTS AND DISCUSSION}

\subsection{Fluorescence imaging}

Figure 2 shows a sound teeth specimen (sample 1). Under UVA excitation, as can be seen in Figure 2B, this sample emitted the blue-green color on a white background. As known that the healthy teeth emits blue or green fluorescence when irradiated with near ultraviolet or violetblue light, respectively. In this work the 380-nm LED emitting band from $370 \mathrm{~nm}$ to $390 \mathrm{~nm}$ was used that was capable of stimulating a broad emission band in the visible region with maximum located at blue - green wavelengths. This supposition will be tested by measuring the fluorescence spectra of this sample in the next subchapter.

Besides blue-green fluorescence observed in sound teeth, the red color appeared in the samples with different types of lesions. Sample 2 with dental calculus (dental plaque) is presented in
Figure 3, where the calculus illuminated the strong red fluorescence. For more detailed observation the calculus region was circled and magnified 10 times (Figure 3C-D). There are about 1,000 out of the 25,000 species of bacteria that are involved with the formation of dental plaque, but microorganisms that form the plaque are mainly Streptococcus mutans and anaerobes, with the composition varying by location in the mouth [14]. It has long been recognized that the bacteria Streptococcus mutans produces special metabolites called porphyrins. Porphyrins are the native fluorophores that strongly emits red light $[11,15]$. The denser the bacterial colonization, the more intense the red fluorescent signal will be.

The red fluorescence was also found in more advanced lesions (dentinal lesions) as can be seen in Figure 4 (sample 3). The mouth contains a wide variety of oral bacteria, but only a few specific species of bacteria are believed to cause 
dental caries: Streptococcus mutans and Lactobacillus species among them. As mentioned above, the bacteria Streptococcus mutans produces porphyrins, which have red fluorescence. There was a significant difference in the fluorescence intensity and color of sample 3 from sample 2, such as the strong red of sample
2 and the pink of sample 3 . The causes of this show may be due to the presence of another fluorophore in sample 3 or just due to the different density of bacteria. Measuring fluorescence spectra of these samples will give the information about this.
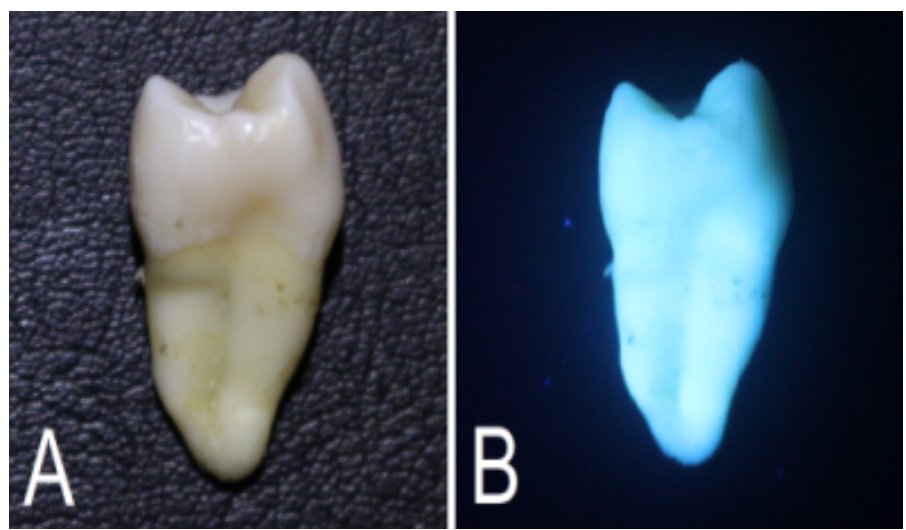

Figure 2. Sample 1: white light (A), fluorescence (B).
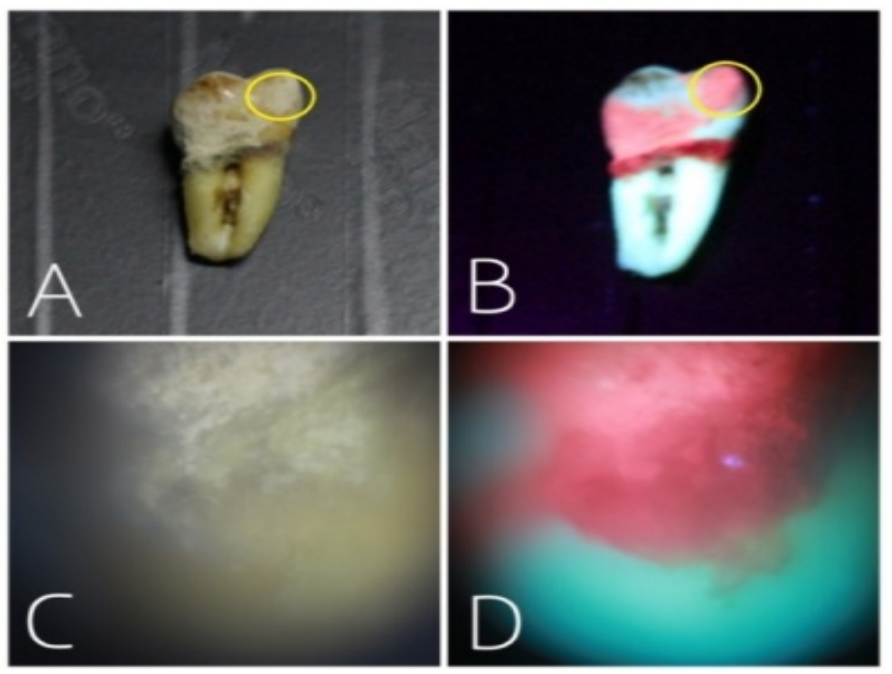

Figure 3. Sample 2: white light and fluorescence (A, B), magnified white light and fluorescence (C, D). 


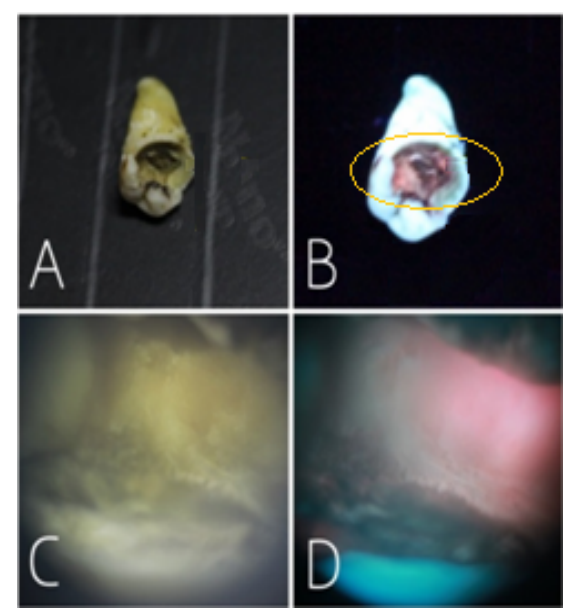

Figure 4. Sample 3: white light and fluorescence (A, B), magnified white light and fluorescence (C, D).

However, the caries expression is not always cavitated as in the case of sample 3. For example, Figure 5A presents sample 4 scored as International Caries Detection \& Assessment System Code 0 (sound tooth). No mark of caries of this sample was found in lit room with normal white light illumination. However under UVA stimulation a small red spot, with careful attention, was caught (Figure 5D). Doubting about the presence of a caries hiding under the enamel layer at an early stage, this area was ground from the surface to the dentin layer until the cavity was appeared (Figure 5B). The result showed not an initial caries but a distinct cavity in the dentin layer.

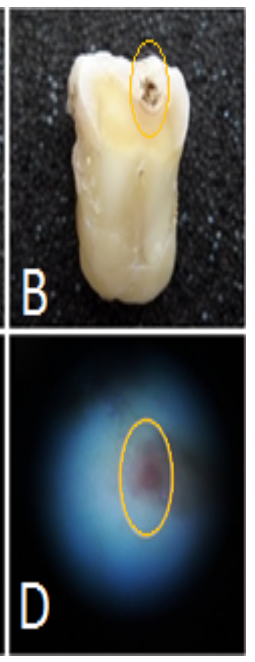

Figure 5. Sample 4: white light before and after grinding (A, B), magnified white light and fluorescence before grinding $(\mathrm{C}, \mathrm{D})$. 


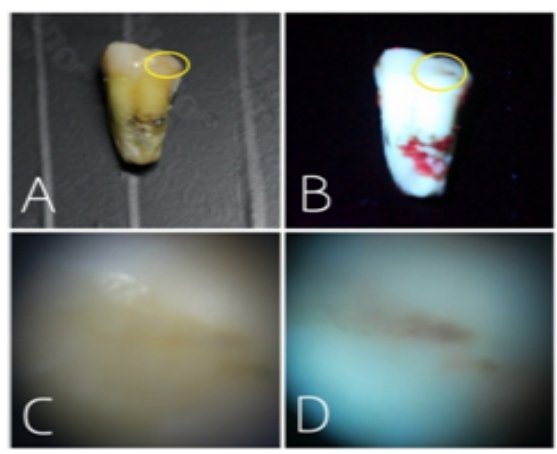

Figure 6. Sample 5: white light and fluorescence (A, B), magnified white light and fluorescence (C, D).

The question is "Where is this caries cavity from?". Note that the enamel layer (thickness 1-3 $\mathrm{mm}$ ) is a filtering membrane allowing the transit of substances from the exterior to the interior, and vice versa. This is because the enamel contains areas with increased water and organic material contents. These zones allow the flow of acids from bacterial plaque, giving rise to disintegration of the organic material and posteriorly conditioning demineralization of the inorganic component - thus supporting the proteolysis - chelation theory of dental caries. These enamel areas with disintegration of the organic material, and the large structural defects such as cracks, which are rich in organic material, can facilitate the penetration of bacteria into deep areas of the enamel, without the existence of superficial cavitation [16].

The next question is "How can the excited light penetrate into the dentin layer at the depth of about 1-2 mm, and on the other hand, the emission light escape from the tooth surface?". For materials with high absorption coefficient $\mu_{a}$ $\left(\mu_{\mathrm{a}} \geq 100 \mathrm{~mm}^{-1}\right)$, the light is absorbed within the first few micrometers of the surface of the tissue. Fortunately, in the visible region, dentin and enamel weakly absorb light $\left(\mu_{\mathrm{a}}<1 \mathrm{~mm}^{-1}\right)$, and light scattering plays an important role in determining the deposited energy distribution in the tissue [17]. In the study of Chen Q.G. et al. [18], the dependence of excited light (405 nm) and autofluorescence $(500 \mathrm{~nm})$ density distribution inside the teeth model on the scattering coefficient $\mu_{\mathrm{s}}$ of enamel $\left(\mu_{\mathrm{s}}=5-25\right.$ $\left.\mathrm{mm}^{-1}\right)$ and dentine $\left(\mu_{\mathrm{s}}=100-140 \mathrm{~mm}^{-1}\right)$ is numerically simulated and analyzed. The results showed that the fluence at the end of enamel layer is over $95 \%$ of the value on the surface. The photons are almost completely absorbed at the depth of 3,7 $\mathrm{mm}$. In the case of sample 4, the caries was found at the depth of 1-2 mm. At this depth, the excited light can completely penetrate into the carious area for stimulating, and vice versa, the emission light can escape to the surface for observing. However, the fluorescence signal on the tooth surface was too weak for taking photo by using a 10x-magnification system.

A similar example of tooth with hidden caries emitting red light under UVA illumination is shown in Figure 6. Hidden occlusal caries was defined as a dentinal caries lesion near the occlusal surface of the tooth, visible on a radiograph, where in visual examination the occlusal enamel is seen intact or minimally perforated. Hidden caries present the dentist with challenges in prevention, diagnosis, treatment planning, patient education and research. In this work, the interesting results obtained from the teeth samples with hidden caries show the advantages of fluorescence technique in detecting the presence of hidden caries. 


\subsection{Fluorescence spectra}

So far the studies of dental caries diagnostic method based on fluorescence technique have mainly used fluorescence imaging and fluorescence spectroscopy separately. The application of both qualitative (imaging) and quantitative (spectroscopy) methods can give a full overview about the fluorescence properties of dental caries. As above mentioned, the sound teeth (sample 1) and carious teeth (samples 2 and 3) showed different fluorescence colors under UVA and these results were examined by measuring fluorescence spectra.

The fluorescence spectra of human teeth have been studied in a long time with various exciting wavelength. In majority of cases the spectra have consisted of a broad band from $400 \mathrm{~nm}$ to $700 \mathrm{~nm}$ with a single peak located at different wavelengths in depending on the excitation. A broad band from $400 \mathrm{~nm}$ to $700 \mathrm{~nm}$ have to consisted of some component bands (some peaks) due to some fluorophores. These component bands can be overlapped each other leading to the observed broad band with single peak. Thus it's difficult to analyze the origin of fluorescence in dental hard tissue.

This study intends to find out a measuring method that is available for catching the component fluorescence band of sound teeth. Up to now, to the best of our knowledge, the power LEDs have not been used widely in studying teeth fluorescence. In our work, the 380-nm LEDs with emission band from $370 \mathrm{~nm}$ to 390

$\mathrm{nm}$ were used for exciting all samples. As can be seen in Figure 7, the spectrum of the sound tooth (sample 1) has consisted of a broad band from $410 \mathrm{~nm}$ to $650 \mathrm{~nm}$ with three peaks at about 450 $\mathrm{nm}, 500 \mathrm{~nm}$ and $520 \mathrm{~nm}$. The other sound teeth were measured and have showed the emission spectra with the same shape but with the higher or lower intensity in comparing with sample 1 . With a such wide range of emission wavelength and three maxima from $450 \mathrm{~nm}$ to $520 \mathrm{~nm}$, it's easy to understand the cause of the observation of blue-green fluorescence on the white background in sound teeth (Figure 2). Three peaks shows that there is more than one fluorophore presenting in dental tissue. The intensity of peaks depends on the density of the fluorophores. The fluorescence of the dental material has a direct relation with the mineral content of the enamel and dentin, while the mineral content has a direct relation with caries and the other dental diseases. Based on the intensity of fluorescence peaks the density of the mineral content can be determined. For many years, researchers have studied the origin of natural fluorescence in dental hard tissue but those visible peaks have not been identified. The determination of fluorophores emitting blue green color in sound teeth requires further investigation.

For comparing with the emission spectrum of sound teeth we measured fluorescence spectra of sample 2-3. In the spectrum of sample 2 (Figure 7), besides three peaks as in sample 1, there is three new peaks at $625 \mathrm{~nm}, 650 \mathrm{~nm}$ and $690 \mathrm{~nm}$. This result is agreeable with the other studies that dental calculus contains porphyrins which absorb UVA and emit a fluorescence signal in the visible red spectral region [19]. 


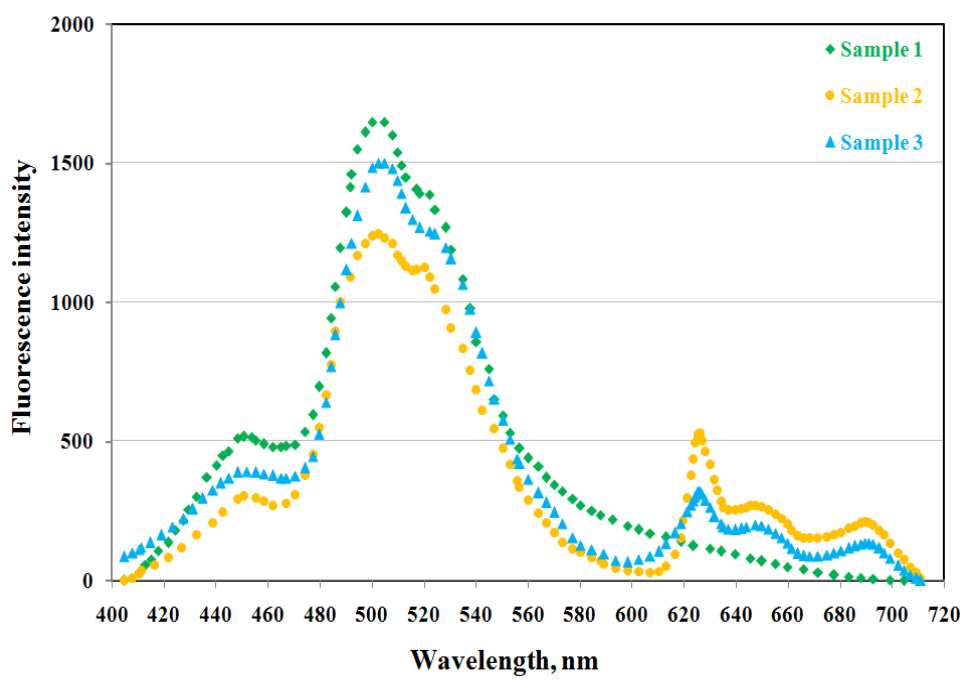

Figure 7. Fluorescence spectra of samples.

The sample 3 was also tested and the result showed the same spectrum as of sample 2 (Figure 7). The porphyrin peaks of sample 3 has the lower intensity than of sample 2. Note that the fluorescence intensity of porphyrins is proportional to the quantity of Streptococcus mutans. The denser the bacterial colonization, the more intense the fluorescence peak will be. The comparision of Figures 3 and 4 shows that, the dental calculus of sample 2 shows the stronger red color than the cavity of samle 3 . The same exhibition of both fluorescence images and spectra indicates that the bacteria density of sample 2 is higher than of sample 3 . Based on the fluorescence images with the naked eye the density of bacteria located on the teeth surface can be predicted.

\section{CONCLUSION}

In this study, we have investigated the fluorescence of sound teeth, teeth with dental calculus, cavitated caries and hidden caries. The sound teeth emitted the blue-green fluorescence on a white background with broad emission spectra from $410 \mathrm{~nm}$ to $650 \mathrm{~nm}$ (with three peaks at $450 \mathrm{~nm}, 500 \mathrm{~nm}$ and $520 \mathrm{~nm}$ ), while the samples with different types of lesions showed the strong red emission with new peaks at 625 $\mathrm{nm}, 650 \mathrm{~nm}$ and $690 \mathrm{~nm}$. Porphyrins, produced by bacteria Streptococcus mutans presenting in lesions, respond to the red fluorescence. The intensity of the red fluorescent signal depends on the density of the bacteria. Under UVA illumination, not only the surface lesions but also the caries hiding under the enamel layer can be detected. This result requires further investigation, but it shows the ability to apply fluorescence technique in the development of a dental diagnostic tool owning a number of advantages such as safety, mobility, low cost and rapid test time.

Acknowledgment: This research is funded by Vietnam National University Ho Chi Minh City (VNU-HCM) under grant number C2015-20-22. 


\section{Ứng dụng kỹ thuật huỳnh quang trong nghiên cứu bệnh sâu răng}

- Phạm Thị Hải Miền

- Trần Văn Tiến

- Huỳnh Quang Linh

Trường Đại học Bách khoa, ĐHQG-HCM

TÓM TÁT:

Mục đích của công trình này là nghiên cứu tính chất huỳnh quang của răng khỏe mạnh và răng tổn thương. Sử dụng diode phát quang trong vùng tử ngoại gần để kích thích răng phát quang đã thu nhận được những hình ảnh và phổ huỳnh quang khác nhau giữa răng khỏe mạnh và răng sâu liên quan tới sụ có mặt của vi khuẩn Streptococcus mutans sinh ra porphyrin tại vị trí sâu. Răng khỏe mạnh phát quang màu xanh lơ với dải phổ huỳnh quang khá rộng chạy từ 410 đến $650 \mathrm{~nm}$ với ba đỉnh tại $450 \mathrm{~nm}, 500 \mathrm{~nm}$ và $520 \mathrm{~nm}$, trong khi khu vực răng sâu phát quang màu đỏ với

ba đỉnh móri tại $625 \mathrm{~nm}, 650 \mathrm{~nm}$ và 690 nm. Cường độ huỳnh quang tỉ lệ thuận với mật độ vi khuẩn tại vị trí sâu. Dựa vào màu đỏ do porphyrins phát ra, không chỉ riêng những tổn thương bề mặt mà cả những vết sâu ẩn dưới lớp men không quan sát được dưới ánh sáng thường cũng sẽ bị phát hiện khi kích thích bằng tia UVA. Những kết quả này cho thấy khả năng ứng dụng kỹ thuật huỳnh quang trong việc phát triển một công cụ chẩn đoán nha khoa ở giai đoạn sớm của bệnh với nhiều ưu điểm như an toàn, cơ động, giá thành thấp và chẩn đoán nhanh.

Từ khóa: huỳnh quang, sâu răng, chẩn đoán sớm.

\section{REFERENCES}

[1]. Michele B.D. et al., Traditional and Novel Caries Detection Methods. Contemporary Approach to Dental Caries. InTech - China (2012).

[2]. Zangooei B.M et al., Dental Caries Diagnostic Methods, DJH 2(1), (2011).

[3]. Lussi A. et al., Detection of approximal caries with a new laser fluorescence device, Caries Research 40(2), 97-103 (2006).

[4]. Sanden E. et al., Reliability of digital radiography of interproximal dental caries, American Journal of Dentistry 16(3), 170-176 (2003).

[5]. Lena Karlsson, Caries Detection Methods Based on Changes in Optical Properties between Healthy and Carious Tissue, International Journal of Dentistry 2010, (2010).

[6]. Alammari M.R. et al., Quantitative light-

induced fluorescence (QLF): A tool for early occlusal dental caries detection and Supporting decision making in vivo, Journal of dentistry 41, 127-132 (2013).

[7]. Sinyaeva M.L. et al., Fluorescence Diagnostics in Dentistry, Laser Physics 14(8), 1132-1140 (2004).

[8]. Lutskaya I.K. et al., Fluorescence of dental hard tissue and restorative materials, 
International dentistry - African edition 2(5), 162-168 (2012).

[9]. Laurence J.W. et al., Ultraviolet-induced fluorescence: shedding new light on dental biofilms and dental caries, Australasian Dental Practice 18(6), 56-60 (2007).

[10].Hibst R.P. et al., New approach on fluorescence spectroscopy for caries detection, Lasers in Dentistry V 141, 141147 (1999).

[11].Hibst R.P. et al., Molecular basis of red excited caries fluorescence, Caries Res. 34, 308-367 (2000).

[12].Shivakumar K.M., International Caries Detection and Assessment System: A new paradigm in detection of dental caries, $J$ Conserv Dent. 12(1), 10-16 (2009).

[13].Duong Phan Hung and Nguyen Van Tuan, Design of optical system for studying emission properties of tissue, Thesis HCMUT (2014).
[14].Laird W.R.E. and Grant A.A., Dental bacterial plaque, International Journal of Biochemistry 15(9), 1095-1102 (1983).

[15].Uzunov T.S. et al., Diagnosis of Dentin Caries - Ultraviolet Fluorescence, Acta Medica Bulgarica 41(2), 55-60 (2014).

[16].Amparo J.P. et al., How to Diagnose Hidden Caries? The Role of Laser Fluorescence, Contemporary Approach to Dental Caries. InTech - China (2012).

[17].Daniel Fried et al., Nature of light scattering in dental enamel and dentin at visible and near-infrared wavelengths, Applied optics 34(7), 1278-1285 (1995).

[18].Q.G. Chen et al., Numerical and Experimental Study of Excited Light and Autofluorescence Diffusion in Teeth, Laser Physics, 2010, Vol. 20, No. 10, pp. 19271934.

[19].Bakhmutov D., Fluorescence spectroscopy of dental calculus, Laser Phys. Lett. 7(5), 384-387 (2010). 